\title{
ANALISIS LOKASI TEMPAT PENAMPUNGAN SAMPAH SEMENTARA (TPSS) KECAMATAN ALALAK KABUPATEN BARITO KUALA, KALIMANTAN SELATAN
}

\author{
Rosalina Kumalawati1) Deasy Arisanty') Muhammad Riswan2) \\ 1) Dosen Program Studi Pendidikan Geografi PIPS FKIP UNLAM \\ 2) Mahasiswa S2 IPS Program Pascasarjana UNLAM \\ E-mail: rosalinaunlam@gmail.com
}

\begin{abstract}
ABSTRAK
Penelitian ini bertujuan untuk: 1) Kesesuaian lokasi Tempat Penampungan sampah Sementara berdasarkan jumlah penduduk, kepadatan dan luas, 2) Mengetahui distribusi lokasi TPSS lama dan lokasi baru yang tepat untuk TPSS; sehingga dapat membantu di dalam pengambilan keputusan kebijakan. Penelitian ini menggunakan metode deskriptif kuantitatif. Dengan populasi seluruh KK di daerah penelitian yaitu 55.338 jiwa. Sampel diambil sebanyak 268 jiwa yang tersebar per Kelurahan/Desa di Kecamatan Alalak.

Hasil dari penelitian ini adalah: 1) TPSS di Kecamatan Alalak lokasinya masih belum tepat berdasarkan pada hasil observasi dan kuesioner yang ditanyakan kepada responden karena keberadaan TPSS yang ada 3 buah di Kecamatan Alalak berada pada satu wilayah yang sama yaitu di Kelurahan Handil Bakti, 2) Keberadaan TPSS yang tidak tersebar dan sangat jauh bagi masyarakat di Kelurahan/Desa yang lain menyebabkan munculnya TPSS liar yang tersebar di beberapa wilayah di Kecamatan Alalak, 3) Setelah di analisis dengan observasi di lapangan ternyata keberadaan TPSS sangat berdekatan, 4) Perlunya penambahan TPSS baru yang letaknya tersebar di Kelurahan/Desa Kecamatan Alalak.
\end{abstract}

\section{Kata kunci: Analisis Lokasi, TPSS, Perencanaan Tata Ruang}

\section{PENDAHULUAN}

Salah satu isu penting dalam masalah lingkungan perkotaan yang dihadapi sejalan dengan perkembangan jumlah penduduk dan peningkatan aktivitas pembangunan adalah sampah. Sampah dalam Tchobanoglous (1977) dalam Hartono E (2006) diistilahkan sebagai limbah padat (solid waste) adalah segala bentuk limbah yang ditimbulkan dari kegiatan manusia maupun binatang yang biasanya berbentuk padat dan secara umum telah dibuang serta tidak bermanfaat atau tidak dibutuhkan lagi. Selaras dengan hal tersebut Kodoatie (2005) dalam Nugroho S (2012) mendefinisikan sampah sebagai limbah atau buangan yang bersifat padat, setengah padat yang merupakan hasil sampingan dari kegiatan perkotaan atau sirkulasi kehidupan manusia, hewan maupun tumbuh-tumbuhan.

Peningkatan volume sampah berkembang secara eksponensial yang belum dibarengi dengan peningkatan pendapatan Pemerintah Daerah yang sepadan untuk pengelolaan sampah kota (Puslitbang
Permukiman, Kalimantan Selatan, 2014). Hal lain berkaitan dengan semakin sulit dan mahalnya untuk mendapatkan lokasi Tempat Pembuangan Akhir (TPA) sampah, juga letaknya yang semakin jauh telah memperpanjang transportasi dan meningkatkan biaya pengangkutannya.

Kemampuan PEMDA pada kota-kota besar dan sedang di Indonesia dalam menangani sampah masih terbatas. Sampah yang tidak terkelola dengan baik merupakan salah satu penyebab makin meningkatnya pencemaran air, tanah dan udara serta meningkatkan potensi banjir di perkotaan. Permasalahan persampahan perlu ditangani secara serius dengan teknik, operasional dan manajemen yang tepat dan terpadu berdasarkan kondisi dan kebijakan daerah masing-masing. Pengelolaan sampah sementara ini dipandang hanya sebagai tanggungjawab pemerintah semata. Masyarakat lebih berperan hanya sebagai pihak yang dilayani, karena mereka merasa sudah cukup hanya dengan membayar uang retribusi sampah sehingga penanganan selanjutnya 
adalah menjadi tanggungjawab pemerintah. Padahal saat ini sudah ada sistem yang lebih baik dan efisien dan dianggap modern yaitu konsep zero waste, dengan menerapkan pengelolaan sampah secara terpadu, mengurangi volume sampah dari sumbernya dengan cara daur ulang dan pengkomposan. Masalah sampah ini juga terjadi di Kabupaten Barito Kuala Propinsi Kalimantan Selatan.

Kabupaten Barito Kuala adalah salah satu di antara 11 kabupaten/kota di Kalimantan Selatan yang memiliki 17 kecamatan. Kecamatan di Kabupaten Barito Kuala yang memiliki kepadatan penduduk yang paling tinggi adalah Kecamatan Alalak (BPS, 2014 dan Hasil Pengolahan, 2015). Daerah yang memiliki kepadatan penduduk tinggi asusmsinya mempunyai sampah yang cukup tinggi juga, hal tersebut yang mendorong peneliti melakukan penelitian di Kecamatan Alalak Kabupaten Barito Kuala.

Pengelolaan persampahan di Kecamatan Alalak Kabupaten Barito Kuala masih menggunakan sistem pengelolaan yang konvensional yaitu metode pengumpulan, pengangkutan ke TPS dan pemusnahan sampah di Tempat Pembuangan Akhir (TPA), pengelolaan sampah ini sangat tergantung pada armada pengangkut sampah. Sampah-sampah tersebut, yang terdiri dari sampah organik dan anorganik yang semuanya diangkut dan dimusnahkan di TPA. Pada sistem konvensional ini diperlukan banyak alat pengangkut sampah seperti: gerobak, becak dan truk pengangkut sampah, rute transportasi truk sampah, lahan penampungan sementara (TPS) serta lahan penampung akhir sampah (TPA) yang luas dan lokasinya jauh dari sumber. Berdasarkan latar belakang tersebut peneliti tertari melakukan penelitian dengan judul "Analisis Lokasi Tempat Penampungan Sampah Sementara (TPSS) Untuk Perencanaan Tata Ruang Kecamatan Alalak Kabupaten Barito Kuala".

\section{METODOLOGI PENELITIAN}

Tujuan penelitian ini adalah untuk: 1) Kesesuaian lokasi Tempat Penampungan sampah Sementara berdasarkan jumlah penduduk, kepadatan dan luas, 2) Mengetahui distribusi lokasi TPSS lama dan lokasi baru yang tepat untuk TPSS; sehingga dapat membantu di dalam pengambilan keputusan kebijakan. Penelitian ini menggunakan metode deskriptif kuantitatif.

Dengan populasi seluruh KK di daerah penelitian yaitu 55.338 jiwa, maka sampel diambil sebanyak 268 jiwa yang tersebar per Kelurahan/Desa di Kecamatan Alalak yang dipilih secara purposive sampling.

\section{HASIL DAN PEMBAHASAN}

\section{Kesesuaian Lokasi TPSS}

Lokasi kegiatan yang melayani kebutuhan penduduk harus berada pada tempat yang sentral dalam hal ini Lokasi TPSS. Tempat yang lokasinya sentral adalah tempat yang memungkinkan partisipasi manusia yang jumlahnya maksimum, baik bagi mereka yang terlibat dalam aktifitas pelayanan maupun yang menjadi konsumen dari barang-barang dan pelayanan yang dihasilkannyav(Sumaatmadja, 1988). Lokasi TPSS yang sesuai harus memenuhi kriteria yang ada yaitu aksesibilitas, jarak dan biaya.

Kesesuaian lokasi TPSS di daerah penelitian berdasarkan hasil pengolahan data primer dan data sekunder diperoleh bahwa lokasi TPSS yang ada sangat tidak sesuai dengan harapan masyarakat di daerah penelitian (lihat Tabel 1). Hasil kesesuaian lokasi TPSS sangat tidak sesuai $(88,06 \%)$ karena keberadaan TPSS yang ada ada hanya 3 buah dan berada pada satu wilayah yang sama yaitu di Kelurahan Handil Bakti. Keberadaan TPSS yang tidak tersebar dan sangat jauh bagi masyarakat di Kelurahan/Desa yang lain menyebabkan munculnya TPSS liar di daerah penelitian.

2. Distribusi Lokasi TPSS

Hasil analisis distribusi lokasi TPSS berdasarkan persepsi masyarakat di daerah penelitian menunjukkan bahwa distribusi lokasi TPSS yang ada di daerah penelitian juga sangat tidak sesuai $(89,55 \%)$ dengan yang diharapkan masyarakat. Lokasi TPSS yang diharapkan masyarakat adalah dekat dengan tempat tinggal, aksesibilitas yang mudah dan biaya transportasi yang murah. Kenyataannya TPSS yang ada lokasinya terpusat pada satu lokasi dan jaraknya jauh dari permukiman penduduk, hal tersebut 
mengakibatkan biayanya mahal (lihat Tabel 2). Jauhnya lokasi TPSS yang ada dan mahalnya biaya transportasi untuk mengangkut sampah yang ada mendorong munculnya TPSS liar di daerah penelitian.

Tabel 1. Kesuaian Lokasi TPSS

\begin{tabular}{clrc}
\hline Skor Kesesuaian & Kriteria & Jumlah & Persentase (\%) \\
\hline$\geq 12$ & Sangat Sesuai & 0 & 0,00 \\
$9-11$ & Sesuai & 2 & 0,75 \\
$6-8$ & Kurang Sesuai & 6 & 2,24 \\
$3-5$ & Tidak Sesuai & 24 & 8,96 \\
$0-2$ & Sangat Tidak Sesuai & 236 & 88,06 \\
\hline & & $\mathbf{2 6 8}$ & $\mathbf{1 0 0 , 0 0}$ \\
\hline
\end{tabular}

Sumber : Hasil Pengolahan Data Primer, 2015

TPSS liar yang ada mengakibatkan lingkungan daerah penelitian menjadi kotor dan kemungkinan dapat menimbulkan wabah penyakit kalau dibiarkan terus menerus akibat semakin banyaknya sampah yang berserakan.

Tabel 2. Distribusi Lokasi TPSS

\begin{tabular}{clrc}
\hline Skor Kesesuaian & \multicolumn{1}{c}{ Kriteria } & Jumlah & Persentase (\%) \\
\hline$\geq 12$ & Sangat Sesuai & 0 & 0,00 \\
$9-11$ & Sesuai & 0 & 0,00 \\
$6-8$ & Kurang Sesuai & 9 & 3,36 \\
$3-5$ & Tidak Sesuai & 19 & 7,09 \\
$0-2$ & Sangat Tidak Sesuai & 240 & 89,55 \\
\hline & Total & $\mathbf{2 6 8}$ & $\mathbf{1 0 0 , 0 0}$
\end{tabular}

Sumber : Hasil Pengolahan Data Primer, 2015

3. AnalisisLokasi TPSS

Analisis lokasi TPSS di daerah penelitian menunjukkan fakta dilapangan yaitu bahwa di beberapa titik lokasi TPSS yang dekat dengan lokasi pasar atau permukiman padat seringkali sampah tidak dapat tertampung dengan baik pada tempatnya. Dalam hal ini besarnya dimensi TPSS tipe terbuka sangat penting agar dapat menampung seluruh sampah yang ada, selain dimensi TPSS perlu juga diperhitungkan lahan untuk TPSS tersebut agar memudahkan proses pengangkutan dari TPSS ke Tempat Pemrosesan Akhir (TPA). Pemilihan jenis dan kapasitas kontainer sampah ditentukan oleh karakteristik dan jenis sampah, sistem dan frekuensi pengumpulan sampah, serta lokasi di mana tempat sampah akan diletakkan (Tchobanoglous et al., 1993).
4. Arahan Pengambilan Kebijakan berdasarkan Tata Ruang

Penentu kebijakan dalam hal ini adalah beberapa politikus, dan mayoritas anggota perwakilan rakyat belummerespon, betapa kompleks dan pentingnya pengelolaan persampahan. Pada saat eksekutif mengajukan/mengusulkan tentang anggaran yang berkaitan dengan pengelolaan sampah, perhatian dari anggota perwakilan rakyat masih rendah, sehingga agenda pembahasan pengelolaan persampahan menjadi prioritas terakhir untuk disetujui. Keadaan yang paling buruk terjadi, ketika para pembuat keputusan/penentu kebijakan dalam pemerintahan mempunyai kesadaran yangrendah dalam masalah pengelolaan persampahan. Apabila para pembuat keputusan/penentu kebijakan dalam pemerintahan mempunyai kesadaran yang tinggi dalam masalah pengelolaan 
persampahan maka masalah sampah tersebut dapat segera dapat diatasi dengan baik.

Selain diperlukan adanya kesadaran yang tinggi dari para penentu kebijakan juga sangat diperlukan adanya penambahan lokasi TPSS yang baru dan lokasinya tersebar merata di seluruh daerah penelitian yang ada. Berdasarkan Undang-Undang Nomor 18 Tahun 2008 tentang Pengelolaan Sampahpasal 1 mendefinisikan sampah sebagai sisa kegiatan sehari-hari manusia dan/atau proses alam yang berbentuk padat. Pengertian sampah pada SNI 19-2454-1991 tentang Tata Cara Teknik Operasional Pengelolaan Sampah adalah limbah yang bersifat padat terdiri dari bahan organik dan bahan anorganik yang dianggap tidak berguna lagi dan harus dikelola agar tidak membahayakan lingkungan danmelindungi investasi pembangunan. Sedangkan timbulan sampah adalah banyaknya sampah yang timbul dari masyarakat dalam satuan volume maupun berat perkapita perhari, atau perluas bangunan, atau perpanjang jalan. Melihat penjelasan tersebut jelas bahwa sampah akan terus bertambah dan semakin menumpuk apabila tidak adanya pengelolaan sampah yang tepat dan didukung oleh para penentu kebijakan.

\section{KESIMPULAN}

1. Kesesuaian lokasi TPSS sangat tidak sesuai $(88,06 \%)$ karena keberadaan TPSS yang ada ada hanya 3 buah dan berada pada satu wilayah yang sama yaitu di Kelurahan Handil Bakti,

2. Distribusi lokasi TPSS yang ada di daerah penelitian juga sangat tidak sesuai $(89,55 \%)$ dengan yang diharapkan masyarakat. Lokasi TPSS yang diharapkan masyarakat adalah dekat dengan tempat tinggal, aksesibilitas yang mudah dan biaya transportasi yang murah,

3. Analisis lokasi TPSS di daerah penelitian menunjukkan fakta dilapangan yaitu bahwa di beberapa titik lokasi TPSS yang dekat dengan lokasi pasar atau permukiman padat seringkali sampah tidak dapat tertampung dengan baik pada tempatnya,

4. Penentu kebijakan dalam hal ini adalah beberapa politikus, dan mayoritas anggota perwakilan rakyat belum merespon, betapa kompleks dan pentingnya pengelolaan persampahan.

\section{DAFTAR PUSTAKA}

Badan Pusat Statistik (BPS) Kabupaten Barito Kuala., 2014. Kabupaten dalam Angka, Barito Kuala: BPS Kabupaten Barito Kuala.

Hartono, Edi. 2006. Peningkatan Pelayanan Pengelolaan Sampah di Kota Brebes melalui Peningkatan Kemampuan Pembiayaan. Program Pascasarjana Magister Teknik Pembangunan Wilayah dan Kota Universitas Diponegoro, Semarang.

Nugroho, Sigit, 2012. Proyek Akhir Analisis Kebutuhan Sarana dan Prasarana Sampah Domestik Berbasis Pewilayahan di Kota Kediri.Kota Kediri.

Suharsimi, A., 1966. Prosedur Penelitian Suatu Pendekatan Praktek. Jakarta: PT. Rineka Cipta.

Undang-Undang Nomor 18 Tahun 2008 tentang Pengelolaan Sampah Pasal 1 SNI 19-2454-1991 tentang Tata Cara Teknik Operasional Pengelolaan Sampah 